\title{
WHAT IS THE RELATIONSHIP AMONG HERNANDIACEAE, LAURACEAE, AND MONIMIACEAE, AND WHY IS THIS QUESTION SO DIFFICULT TO ANSWER?
}

\author{
Susanne S. Renner ${ }^{1}$ and André S. Chanderbali ${ }^{2}$ \\ Department of Biology, University of Missouri, St. Louis, Missouri 63121, U.S.A.; \\ and Missouri Botanical Garden, St. Louis, Missouri 63166, U.S.A.
}

\begin{abstract}
Molecular and morphological phylogenetic studies in the Laurales have found that Hernandiaceae, Lauraceae, and Monimiaceae sensu stricto form a monophyletic group. Because of the paucity of phylogenetically informative substitutions, however, relationships among families within this clade remain unclear. In general, molecular phylogenies may conflict because of a variety of factors, including substitution rate variation among sites and lineages, taxon sampling, outgroup choice, and base compositional biases. We analyzed a total of 2846 aligned nucleotides from a plastid intron, three spacers, and a portion of the nuclear 26S rRNA gene in a sample of Hernandiaceae, Lauraceae, and Monimiaceae; we used four outgroups with differing substitution rates. Despite obtaining single best topologies with maximum likelihood, minimum evolution, and parsimony approaches, family relationships remained as poorly supported as they were in the previous molecular studies. Exploration of the data indicates that varying substitution rates across lineages or sites, insufficient taxon sampling, fast-evolving outgroups, or biased base composition are unlikely to explain the difficult reconstruction. Exclusion of some of the longest branched taxa (the hemiparasite Cassytha, selected Hernandiaceae, and two of the four outgroups) had no effect on topologies. To resolve relationships among the three families one could now complement existing five-gene data sets by adding the basal genera of Lauraceae, Monimiaceae, and Hernandiaceae, which are newly sampled here, or, our preferred strategy, by sequencing low-copy nuclear genes for the key genera to obtain different kinds of data.
\end{abstract}

Keywords: Hernandiaceae, Lauraceae, Cassytha, Monimiaceae, substitution rate variation in 26S, rpl16, $t r n \mathrm{~T}-\mathrm{L}, t r n \mathrm{~L}-\mathrm{F}, p s b \mathrm{~A}-t r n \mathrm{H}$.

\section{Introduction}

The Laurales comprise seven families, ca. 85 genera, and at least 2400 species (APG 1998; Qiu et al. 1999; Renner 1999). Within Laurales, the oldest split is between the predominantly temperate Calycanthaceae and the six remaining predominantly tropical families (Renner 1999). The latter form two clades, one comprising Siparunaceae, with Atherospermataceae and Gomortegaceae as sister groups, and a second comprising Hernandiaceae, Lauraceae, and Monimiaceae (hereafter the HLM clade). This topology for the order was obtained from an analysis of sequences from the chloroplast (cp) rbcL gene, three spacer regions, and an intron, with sampling of 25 genera of Laurales, 11 of which were from the HLM clade (aligned length 4402 base pairs [bp]; Renner 1999). The same two major clades in Laurales were found when five genes from the three plant genomes were combined in a study of the basal angiosperms and of their relationships to gymnosperms (Qiu et al. 1999). The latter study included 15 genera of Laurales, seven of which were from the HLM clade, and genes from the chloroplast (atp B and $r b c \mathrm{~L}$ ), mitochondrion (atp1 and mat $\mathrm{R}$ ), and nucleus (18S rDNA), with an aligned length of $8733 \mathrm{bp}$. The two molecular studies differ in their placement of Her-

\footnotetext{
${ }^{1}$ Author for correspondence; e-mail biostenn@admiral.umsl.edu.

2 E-mail chanderb@mobot.mobot.org.
}

Manuscript received March 2000; revised manuscript received May 2000. nandiaceae, a pantropical family of five genera and 60 species. In the cpDNA gene/spacer/intron study, Hernandiaceae were sister to Monimiaceae + Lauraceae. In the three genomes/five genes study, Hernandiaceae appeared as sister to Monimiaceae. Neither relationship was well supported $(<80 \%$ bootstrap support in the first case, $<50 \%$ in the second).

Hernandiaceae (4-5 genera/60 species; Kubitzki 1993), Monimiaceae (22-25 genera/200 species; Renner 1998; Renner and Zanis 1999), and Lauraceae (50 genera/2500-3000 species; Rohwer 1993, 2000; Chanderbali et al., in press) are united within Laurales by apically positioned ovules (the single ovule is inserted at or near the locule apex). In contrast, their sister clade-Siparunaceae, Atherospermataceae, and Gomortegaceae-has basal ovules (ovules inserted at or near the base of the locule), except for Gomortega, which has highly derived syncarpous two- to three-locular pistils with apical ovules. Based on morphology, Hernandiaceae appear closest to Lauraceae (Doyle et al. 1994, fig. 8b; Renner et al. 1997, fig. 5; Doyle and Endress 2000). Characters supporting a relationship between Lauraceae and Hernandiaceae, to the exclusion of Monimiaceae, are unicarpellate flowers and endospermless mature seeds. Other characters, such as phyllotaxy and anthotaxy, have also been adduced to support a sister group relationship between Lauraceae and Hernandiaceae, but these patterns are not straightforward. Lauraceae have alternate, opposite, or whorled leaves; Hernandiaceae have alternate leaves; and Monimiaceae have decussate or whorled leaves. 
Flowers of Lauraceae have two whorls of usually three tepals each. Hernandiaceae have two whorls of 3-5(-6) tepals or a single whorl of 4-7(-8) tepals. Monimiaceae have 10-20 spirally arranged tepals (Hortonia and Peumus) or, more commonly, 4-6(-8) tepals in two whorls. Wood anatomy supports a close relationship between Hernandiaceae and Monimiaceae but also between Hernandiaceae and Lauraceae (Shutts 1960). Kubitzki (1969, p. 119), the most recent monographer of Hernandiaceae, thought that Hernandiaceae "might be closest to Lauraceae," but did not provide details. Takhtajan (1973, p. $116 ; 1997$, p. 58), probably following Baillon (1869, esp. pp. 324-325), suggested that Lauraceae originated from primitive Monimiaceae such as Hortonia. Even so, he placed Hernandiaceae and Lauraceae in a suborder separate from Monimiaceae (Takhrajan 1997, p. 57). The idea that Hernandiaceae, taken out of Lauraceae and established as a separate family by Blume in 1825 , should be reunited with Lauraceae has a long history (Meissner 1864; Baillon 1869; Hallier 1905; Gunderson 1950). However, these morphology-based analyses and systems were hampered by the prevailing wide concept of Monimiaceae, which included Siparunaceae and Atherospermataceae in Monimiaceae. This broad circumscription of Monimiaceae greatly confused character analyses in Laurales, because Monimiaceae sensu lato comprise almost the entire range of character states found in Laurales.

As expected from the difficulty inherent in reconstructing exact relationships in the HLM clade and from the clade's great age, each of the families has numerous autapomorphies in terms of morphology as well as DNA sequences. About 40 genera and more than 500 lauraceous species are known from the Early Cretaceous through to the Late Tertiary (Eklund and Kvacek 1998; Eklund 1999). The fossil record of Hernandiaceae and Monimiaceae is poorer, but it still reaches back to the Paleocene, and the HLM sister clade, comprising Siparunaceae, Gomortegaceae, and Atherospermataceae, goes back to the Eocene (Renner et al. 2000).

Low statistical support or contradictory results in molecular studies are commonly attributed to insufficient information from short sequences, poor taxon sampling, strong rate variation across nucleotide sites or taxa, compositional biases, paralogy, hybridization, or a combination of these factors. To improve phylogenetic inference from DNA data, several strategies have been suggested: (1) increasing the number of variable nucleotides will increase the chance of obtaining a known true tree (Cummings et al. 1995; Hillis 1996; Graybeal 1998; Soltis et al. 1998; Bremer et al. 1999; Poe and Swofford 1999). However, it is unclear how many nucleotides will suffice to solve a specific problem; Qiu et al. (1999) analyzed 8733 aligned $\mathrm{bp}$, albeit for a different set of taxa because they focused on the entire basal angiosperms, yet they were unable to resolve family relationship in the HLM clade (seven genera from this clade were included). Empirical and theoretical studies have shown that even data sets with a large number of characters can fail to find known true relationships when substitution rates vary extensively across lineages or sites (e.g., Kuhner and Felsenstein 1994; Takezaki and Gojobori 1999; but see Hillis 1996; Kim 1998; Rannala et al. 1998). Given that the studies performed so far have not resolved HLM relationships, we concentrate here on taxon sampling and methods of tree reconstruction that incorporate heterogeneity in explicit models rather than length of sequence. Long-branch effects caused by lineages with numerous autapomorphic nucleotide substitutions affect parsimony more than do other tree reconstruction methods, such as maximum likelihood (ML) and corrected-distance methods (e.g., Li 1997, pp. 127-136). The latter consider undetected changes and are therefore less likely to be affected by rate heterogeneity among taxa if the assumed models of sequence evolution are appropriate (Swofford et al. 1996; Li 1997; Poe and Swofford 1999). (2) Dense and judicious sampling to break up long branches also can improve the possibility of finding a known true tree (Lecointre et al. 1993; Hillis 1996; Graybeal 1998; Kim 1998; Rannala et al. 1998). We obtained sequences from four of the five currently recognized genera of Hernandiacene (Kubitzki [1993] recently raised the single species of Hernandia subgenus $\mathrm{Ha}$ zomalania to genus rank, but he now considers this rank change to have been unjustified; K. Kubitzki, personal communication to S. S. Renner, 2000). For Lauraceae, we included eight genera, representing the major lineages of Lauraceae (Rohwer 2000; Chanderbali et al., in press; the latter molecular phylogenetic study includes representatives from 44 of the 50 genera of Lauraceae). For Monimiaceae, we included the four of the family's 15-22 genera that represent the deepest splits in that family (Renner 1998, 1999; Renner and Zanis 1999). Thus, 16 genera were sampled from the HLM clade, as opposed to the seven sampled previously. (3) Long-branch effects can also be introduced by the inclusion of too-distant or fastevolving outgroup taxa, as observed in studies of basal angiosperms (Chase et al. 1993), vertebrates (e.g., Takezaki and Gojobori 1999), and in statistical analyses of the effects of outgroup rate variation (Lyons-Weiler et al. 1998). We sampled four outgroup taxa, including the sister taxon of the HLM clade, which comprises two slow- and one fast-evolving lineage, and a more distant outgroup in order to explore the effect of outgroup substitution rate heterogeneity on ingroup topology. (4) Because different genomes and genome regions, such as introns, intergenic spacers, and genes, are under different selection regimes, sampling different regions and genomes may even out the effects of location-dependent differences in sequence evolution (Cummings et al. 1995). Our data matrix combines a chloroplast intron and three spacers with a portion of the nuclear 26S rRNA gene. (5) Any method of tree reconstruction may become inconsistent when sequences differ in their base compositions, because standard corrections for multiple changes assume that nucleotides are equally abundant in all sequences. We, therefore, explored a possible compositional bias in the Laurales sequences by performing a $\chi^{2}$ test on the nucleotide frequencies observed in the different taxa.

We ask two questions: (1) What is the relationship among Hernandiaceae, Lauraceae, and Monimiaceae? and (2) What makes obtaining a robust molecular phylogeny for these taxa so difficult?

\section{Material and Methods}

\section{Taxon Sampling}

Taxa sequenced for this study are listed in the appendix, which also provides source and voucher information and lists GenBank accession numbers for the 118 sequences analyzed, 
56 of which were newly generated for this study. Lauraceae are represented by eight genera and nine species (in three instances, sequences from two species were combined; see below), chosen to represent all major clades (Rohwer 1993, 2000; Chanderbali et al., in press). Basal Lauraceae are represented by the monotypic African Hypodaphnis, which is apparently the sister group to all other Lauraceae, and by Cryptocarya, Beilschmiedia, and Caryodaphnopsis. Higher Lauraceae are represented by Sextonia, Ocotea, and Litsea. We also included an Old World and a New World species of Cassytha, a pantropical hemiparasitic genus of problematic placement (Rohwer 1993, 2000). Monimiaceae are represented by four genera from their two main lineages (Renner 1998, 1999; Renner and Zanis 1999). For Hernandiaceae, 10 species representing four of their five genera were included, albeit not in all analyses.

We examined the effects of the variable inclusion of the following four outgroup taxa on ingroup topology: Siparuna (Siparunaceae), Doryphora (Atherospermataceae), Gomortega (Gomortegaceae), and Calycanthus (Calycanthaceae).

The final data matrix consisted of concatenated sequences from 27 taxa (usually from a single total DNA extract), with the following exceptions (appendix): sequences were combined from Beilschmiedia brenesii and Beilschmicdia tilaranensis, Litsea coreana and Litsea glaucescens, Ocotea grayi and Ocotea quixos, Siparuna aspera and Siparuna guianensis, Hernandia guianensis, Hernandia moerenhoutiana, and Hernandia nymphaeifolia, and Sparattanthelium septentrionale and Sparattanthelitm wonotobocnsis. Species of Hernandiaceae with incomplete sequences were scored as ambiguous for regions not sequenced and were excluded from ML analyses.

\section{Genome Regions Sequenced and Laboratory Methods}

Total DNA was isolated from silica gel-dried or herbarium leaves using DNeasy plant mini kits (QIAGEN), according to the manufacturer's instructions. Polymerase chain reaction (PCR) amplification followed standard protocols, with $32 \mathrm{cy}-$ cles of $94^{\circ} \mathrm{C}$ for $30 \mathrm{~s}, 52^{\circ} \mathrm{C}$ for $30-60 \mathrm{~s}$, and $72^{\circ} \mathrm{C}$ for $60 \mathrm{~s}$. The large intron in the chloroplast rpl16 gene was amplified using primers 1067F and 18R designed by Asmussen (1999). To amplify the chloroplast $t r n \mathrm{~T}-t r n \mathrm{~L}$ and $t r n \mathrm{~L}-t r n \mathrm{~F}$ intergenic spacer regions, we used the universal primers $a, b, e$, and $f$ of Taberlet et al. (1991). The trnL-trnF spacer sequences analyzed here begin near the $5^{\prime}$ end of the spacer and include $138 \mathrm{bp}$ of the $S^{\prime}$ end of the tRNA-Phe (trnF) gene. The spacer between the tRNA-Leu $(t r n \mathrm{~L})$ and tRNA-Thr $(t r n \mathrm{~T})$ genes consists of a highly variable $5^{\prime}$ end and a conserved $3^{\prime}$ end. The latter aligns readily with available $t r n \mathrm{~T}-\mathrm{L}$ sequences, for example, those from Dioscorea (84\% sequence similarity in GenBank BLAST searches) and Allizm (72\% sequence similarity). By contrast, the $S^{\prime}$ end varies drastically among taxa and contains numerous short repeats and apparent inversions. For the present analyses, we included only the conserved $3^{\prime}$ end of the $t r n$ T-trnL region. The $p s b \mathrm{~A}-t r n \mathrm{H}$ intergenic spacer was amplified using primers designed by Sang et al. (1997), which generated sequences consisting of 44 bp of the $3^{\prime}$ end of the $p s b \mathrm{~A}$ gene, $\sim 530 \mathrm{bp}$ of the rapidly diverging $p s b \mathrm{~A}-t r n \mathrm{H}$ spacer, and $29 \mathrm{bp}$ of the $5^{\prime}$ end of the tRNA-His $(\operatorname{tr} n \mathrm{H})$ gene. Because of alignment difficulties among Hernandiaceae and the re- maining taxa, we used only the first half of the spacer in the analyses. The $5^{\prime}$ region that includes the first two expansion domains of the nuclear 265 rRNA gene was amplified using the forward primer $27 \mathrm{~F}$ (D. Nickrent, unpublished manuscript) and the reverse primer 641R (Kuzoff et al. 1998). In the analyses, we included the conserved core between positions 57 and 111 , the first expansion segment between positions 111 and 270 , and the second expansion segment between positions 430 and 641 . Four base pairs between positions 474 and 477 were excluded from the analyses because of alignment ambiguity.

PCR products were purified either by running the entire product on a low-melting-point agarose gel and then recovering the amplified DNA with QIAquick gel extraction kits (QIAGEN) or by using the QIAquick PCR purification columns directly without a prior gel purification step. Cycle sequencing of the amplified products was conducted with the ABI Prism Dye Terminator Cycle Sequencing Ready Reaction Kit (Perkin Elmer, Norwalk, Conn.), using $2.5 \mathrm{ng}$ of primer in a $5-\mu \mathrm{L}$ reaction volume. Sequencing reactions were purified by ethanol precipitation and were run on ABI 373 or ABI 377 automated sequencers. Both strands of DNA were sequenced and used to generate a consensus sequence using Sequencher software (GeneCodes, Ann Arbor, Mich.). Sequences were aligned manually, and except for the ends of the $t r n \mathrm{~T}-t r n \mathrm{~L}$ and $p s b A-t r n H$ spacers (which were excluded; see above) and a region of four nucleotides in the $26 \mathrm{~S}$ gene, there were no "difficult-to-align" regions.

\section{Phylogenetic Analyses}

Phylogenetic analyses of the aligned sequences were conducted with test version 4.0b.4 of PAUP* (Swofford 1998). ML analyses were performed using the general time-reversible model (GTR; Yang 1994), which estimates probabilities for the six possible nucleotide substitutions in addition to accounting for unequal base frequencies, transition/transversion bias, and substitution rate heterogeneity across nucleotide sites. To assess whether this parameter-rich model fit our data significantly better than the simpler Hasegawa-Kishino-Yano model (HKY85; Hasegawa et al. 1985), we performed a likelihood ratio test on the highest likelihoods obtained under these two models, using four degrees of freedom (cf. Sullivan et al. 1999). For both models, the proportion of invariable sites, $\mathrm{P}_{\mathrm{inv}}$, and the shape of the parameter, $\alpha$, were estimated simultaneously using the discrete gamma approximation of Yang (1994; implemented in PAUP*), with four rate categories to approximate the continuous gamma distribution. Both models yielded the same single best tree, and the likelihood ratio test rejected the HKY 85 model in favor of the GTR model $\left[\ln L=2(13,408.65758-13,372.37166)=\chi^{2}=72.57 ; P<\right.$ $0.001 ; \mathrm{df}=4 \mathrm{]}$. We therefore selected the GTR-invariable-sitesplus-gamma model as that which was most appropriate to our data.

Rate heterogeneity across sites affects the performance of different tree reconstruction methods, and its estimation has received considerable attention (Yang 1996; Sullivan et al. 1999; Takezaki and Gojobori 1999). To mitigate the potentially deleterious effects of rate variation, one can combine an invariable-sites model with a gamma-distributed-rates model. In the former, some proportion of sites $\left(P_{\text {inv }}\right)$ is assumed to be 
Table 1

Descriptive Statistics for Separate and Combined Data Partitions for the Full Set of 27 Taxa of Laurales

\begin{tabular}{|c|c|c|c|c|c|c|}
\hline Data partition & $\begin{array}{l}\text { rpl16 } \\
\text { intron }\end{array}$ & $\begin{array}{l}t r n \mathrm{~T}-t r n \mathrm{~L} \\
\text { spacer }\end{array}$ & $\begin{array}{c}\text { trnL-trnF } \\
\text { spacer }\end{array}$ & $\begin{array}{c}\text { psbA-trnH } \\
\text { spacer }\end{array}$ & $\begin{array}{l}26 \mathrm{~S} \text { rDNA } \\
\text { gene }\end{array}$ & $\begin{array}{l}\text { Combined } \\
\text { data }\end{array}$ \\
\hline $\begin{array}{l}\text { Aligned nucleotides .......... } \\
\text { Autapomorphic variable sites } \\
\text { (percentage of total }\end{array}$ & 1023 & 519 & 529 & 170 & $605 / 601^{\bullet}$ & $2846 / 2842^{2}$ \\
\hline characters) $\quad \ldots \ldots \ldots \ldots \ldots \ldots$ & $\begin{array}{l}134 \\
(13)\end{array}$ & $\begin{array}{c}80 \\
(15)\end{array}$ & $\begin{array}{c}90 \\
(17)\end{array}$ & $\begin{array}{c}26 \\
(15)\end{array}$ & $\begin{array}{c}66 \\
(11)\end{array}$ & $\begin{array}{l}396 \\
(14)\end{array}$ \\
\hline Informative sites (percentage & & & & & & \\
\hline of total characters) ........ & $\begin{array}{l}205 \\
(20)\end{array}$ & $\begin{array}{l}148 \\
(30)\end{array}$ & $\begin{array}{l}129 \\
(25)\end{array}$ & $\begin{array}{c}47 \\
(28)\end{array}$ & $\begin{array}{l}126 \\
(21)\end{array}$ & $\begin{array}{l}652 \\
(23)\end{array}$ \\
\hline A $\ldots \ldots \ldots \ldots \ldots \ldots \ldots \ldots \ldots \ldots \ldots \ldots$ & 27 & $37^{*}$ & 30 & 27 & $20^{*}$ & 28 \\
\hline C $\ldots \ldots \ldots \ldots \ldots \ldots \ldots \ldots \ldots \ldots \ldots$ & 21 & $14^{*}$ & 21 & 16 & $28^{*}$ & 21 \\
\hline 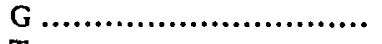 & $16^{*}$ & 24 & 16 & 21 & $37^{*}$ & 23 \\
\hline Number of gaps (gap size & $36^{*}$ & 25 & 33 & 36 & $15^{*}$ & 28 \\
\hline range in bp) $\ldots \ldots \ldots \ldots \ldots \ldots$ & $\begin{array}{c}40 \\
(1-48)\end{array}$ & $\begin{array}{c}19 \\
(1-180)^{b}\end{array}$ & $\begin{array}{c}26 \\
(1-120)^{b}\end{array}$ & $\begin{array}{c}6 \\
(1-12)\end{array}$ & $\begin{array}{c}9 \\
(1-6)\end{array}$ & $\begin{array}{r}100 \\
(1-180)\end{array}$ \\
\hline 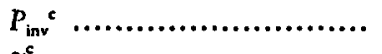 & 0.25 & 0.12 & 0.12 & 0.00 & 0.44 & 0.22 \\
\hline 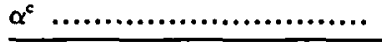 & 1.18 & 2.17 & 3.45 & 0.64 & 0.55 & 0.94 \\
\hline
\end{tabular}

Note. Nucleotide frequencies marked with an asterisk deviate significantly from the mean (Pearson $\chi^{2}$ statistic, $P<0.001$ ).

- Base pairs (bp) 474-477 were eliminated in the final matrix because of alignment ambiguities; only 601 nucleotides of the $26 \mathrm{~S}$ rDNA region were used.

${ }^{b}$ Cassytha has a 180-bp deletion in the aligned $t r n \mathrm{~T}-t r n \mathrm{~L}$ spacer region, and Gyrocarpus has a 135 -bp deletion in the aligned $t r n \mathrm{~L}-t r n \mathrm{~F}$ region.

- Maximum likelihood estimates of proportions of invariable sites and substitution rate heterogeneity parameters ( $\alpha$ ) were obtained under the general-time-reversible model. An $\alpha$ of $>1$ indicates that most sites have intermediate rates, whereas few sites have very low or very high rates. An $\alpha$ of $\leq 1$ indicates that most sites have very low rates or are almost invariable, whereas others change at very high rates (Yang and Kumar 1996). The estimate of $\alpha=0.00$ (i.e., infinity) for the $p s b A-t m H$ spacer, which would imply no rate heterogeneity, probably has a very large variance because it is based on only $170 \mathrm{bp}$.

completely resistant to change; in the latter, the distribution of relative rates over variable sites is assumed to follow a gamma distribution whose shape parameter $(\alpha)$ determines rate heterogeneity. The dependence of $P_{\text {inv }}$ and $\alpha$ on tree topology is minor as long as strongly supported groups are maintained (Yang and Kumar 1996; Sullivan et al. 1999). Therefore, both parameters can initially be estimated for distance trees from the same data, which greatly reduces the computational demands of ML searches with full branch swapping.

Starting trees for ML searches were minimum evolution trees, using log-determinant (LogDet) distances (Lake 1994; Lockhart et al. 1994), and the swapping strategy employed was TBR swapping. We used quartet puzzling (Strimmer and von Haeseler 1996; implemented in PAUP*), a fast tree search algorithm that allows for analysis of large data sets, to obtain estimations of support for internal branches in the ML trees. These values have the same practical meaning as bootstrap values; quartets showing a quartet puzzling reliability of 90\%-100\% are strongly supported (Strimmer and von Haeseler 1996).

Parsimony analyses were performed using heuristic searches, with 10 random addition replicates and TBR swapping. Characters were unweighted and unordered, and gaps were treated as missing data. Nonparametric bootstrap support (Felsenstein 1985 ) for each clade was estimated based on 1000 replicates, using closest taxon addition, TBR swapping, and MULPARS. The COLLAPSE (but not the STEEPEST DESCENT) options of PAUP were in effect during all searches. Most-parsimonious trees were generated independently for the five data sets, fol- lowed by bootstrap analyses, to assess whether conflict among data sets was strongly supported (i.e., had $>80 \%$ bootstrap support). In the absence of such conflict, the data were combined in a global analysis. Characters supporting particular topologies were examined using MacClade 3.04 (Maddison and Maddison 1992).

\section{Results}

\section{Data Characteristics and Phylogenetic Analyses}

Each of the five sequenced DNA regions is characterized in table 1 . The total aligned sequence length comprised 2846 nucleotides, of which four (positions 474-477 in the 265 gene) were eliminated from the analysis because of alignment ambiguity. The final matrix for all 27 taxa contained $652(23 \%)$ parsimony-informative sites and $396(14 \%)$ variable but uninformative sites. As expected, nucleotide composition of the $26 \mathrm{~S}$ gene segment sequenced differed significantly from that of the cpDNA spacers and intron (table 1). Of the 605-bp sequence, $203 \mathrm{bp}$ belong to highly conserved parts of the gene, and the remainder belong to two expansion segments. The average $\mathrm{G}+\mathrm{C}$ content across the sequenced part of the gene was $64 \%$ (i.e., slightly higher than the $56 \%$ characterizing the entire gene and slightly lower than the $66 \%$ found across all expansion segments; Kuzoff et al. 1998). A comparison of nucleotide frequencies shows that there are no significant differences among taxa (table 2). Under parsimony, the ratio of transitions to transversions (ti/tv) across all sequences was 
$1.3: 1(1040-1091 / 799-850)$. The ti : tv ratio was $1.5: 1$ (268-287/177-196) for the $26 \mathrm{~S}$ gene alone. Because parsimony tends to underestimate ti : tv ratios, we also estimated the ti : tv ratio under ML using the HKY model. This gave a ti : tv ratio of $1.5: 1$ across all sequences.

Of the 100 sequence-length mutations (indels), most occurred in the rp/16 intron, and none were phylogenetically informative at the family level. The longest indels occurred in the $\operatorname{trn} \mathrm{T}$-trn L spacer, which comprised between 444 bp in Cassytha filiformis and $840 \mathrm{bp}$ in Siparuna aspera.

Rate heterogeneity across sites in each of the five genome regions is measured by $\alpha$, which is inversely related to the extent of rate variation across sites. Table 1 shows the values for $\alpha$ that were estimated under the GTR model. Only the $26 \mathrm{~S}$ gene shows moderately strong among-site rate heterogeneity. The estimate of $\alpha=0.00$ (i.e., infinity) for the $p s b \mathrm{~A}-t r n \mathrm{H}$ spacer, which would imply no rate heterogeneity, probably has a very large variance since it is based on only $170 \mathrm{bp}$. For the concatenated data, $\alpha$ is close to 1 , indicating an apparently random distribution of the rates at which sites are changing.

The single best tree resulting from the $\mathrm{ML}$ analysis under the GTR-invariable-sites-plus-gamma model (fig. 1) shows Lauraceae to be sister to Hernandiaceae. However, the branch supporting the two families is extremely short, and the grouping was the only one not recovered via quartet puzzling, which we used to obtain confidence values for the ML topology (using the same GTR settings). The puzzle tree instead showed Hernandiaceae to be sister to Monimiaceae, but the support for this clade was only $43 \%$.

After excluding all gapped and ambiguous sites and excluding the seven Hernandiaceae with incomplete sequences, we performed a likelihood ratio test to corroborate the visual impression that substitution accumulation across taxa had not been clocklike. The clock and nonclock analyses had signifcantly different likelihoods $\left(X^{2}=242.5, \mathrm{df}=20, P<\right.$

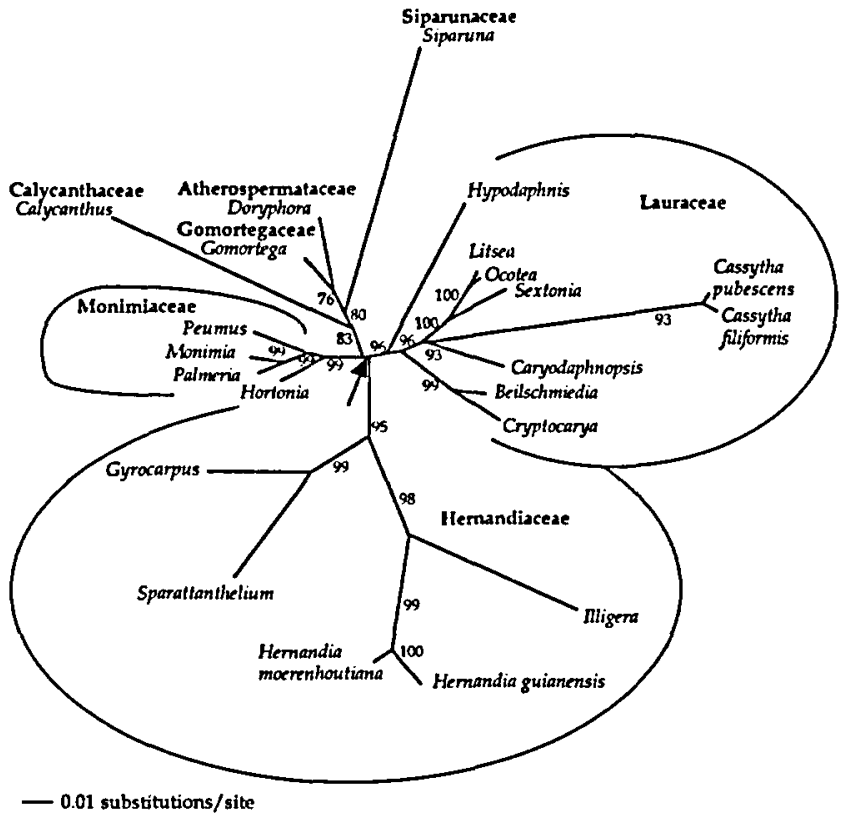

Fig. 1 The highest likelihood tree shown as an unrooted phylogram for Hernandiaceae, Lauraceae, and Monimiaceae. The model used was the GTR-invariable-sites-plus-gamma model. Support values (at nodes) were obtained via quartet puzzling as implemented in PAUP. The Hernandiaceae + Lauraceae clade is supported by an extremely short stem (arrow).

0.0001). From the phylograms (figs. 1-3) it appears that $\mathrm{Ca}$ lycanthus, Siparuna, and Cassytha likely caused most of the rate heterogeneity in the data. The exclusion of these three taxa from the analysis, however, did not change the ML topology or significantly affect the puzzle support values.

Table 2

Nucleotide Frequencies in Different Lineages of Laurales

\begin{tabular}{|c|c|c|c|c|c|}
\hline & A & C & G & $T$ & $\begin{array}{c}\text { Number of } \\
\text { sites }\end{array}$ \\
\hline Beilschmiedia .................... & 0.28 & 0.21 & 0.22 & 0.29 & 2309 \\
\hline Calycantbus ....................... & 0.27 & 0.21 & 0.23 & 0.29 & 2308 \\
\hline Caryodaphnopsis ................. & 0.28 & 0.22 & 0.23 & 0.28 & 2342 \\
\hline Cassytha fliformis ............... & 0.28 & 0.21 & 0.22 & 0.28 & 2177 \\
\hline Cryptocarya ........................ & 0.28 & 0.21 & 0.22 & 0.29 & 2277 \\
\hline Doryphora ...................... & 0.28 & 0.21 & 0.22 & 0.28 & 2329 \\
\hline Gomortega ........................ & 0.28 & 0.21 & 0.22 & 0.29 & 2350 \\
\hline 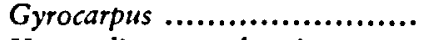 & 0.28 & 0.21 & 0.23 & 0.28 & 2277 \\
\hline Hernandia moerenhoutiana ...... & 0.27 & 0.21 & 0.23 & 0.29 & 2339 \\
\hline Hortonia ........................... & 0.28 & 0.21 & 0.23 & 0.28 & 2342 \\
\hline Hypodaphnis .................... & 0.28 & 0.21 & 0.22 & 0.29 & 2386 \\
\hline Illigera........................ & 0.27 & 0.21 & 0.23 & 0.29 & 2329 \\
\hline Litsea $\quad \ldots . . . \ldots \ldots \ldots \ldots \ldots \ldots \ldots \ldots \ldots$ & 0.28 & 0.21 & 0.23 & 0.28 & 2355 \\
\hline Monimia....$\ldots \ldots \ldots \ldots \ldots \ldots \ldots \ldots$ & 0.28 & 0.21 & 0.22 & 0.29 & 2335 \\
\hline Ocotea.....$\ldots \ldots \ldots \ldots \ldots \ldots \ldots \ldots$ & 0.28 & 0.21 & 0.23 & 0.28 & 2374 \\
\hline 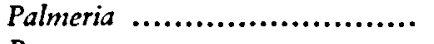 & 0.28 & 0.21 & 0.22 & 0.29 & 2344 \\
\hline 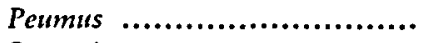 & 0.28 & 0.21 & 0.22 & 0.29 & 2352 \\
\hline Sextonia ........................... & 0.28 & 0.21 & 0.22 & 0.28 & 2355 \\
\hline 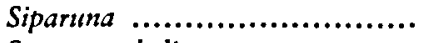 & 0.28 & 0.21 & 0.22 & 0.29 & 2355 \\
\hline Sparattanthelitum .................. & 0.27 & 0.21 & 0.23 & 0.29 & 2297 \\
\hline
\end{tabular}


The minimum evolution tree (fig. 2), using LogDet distances and $P_{\text {inv }}=0.22$ as estimated under ML, shows Hernandiaceae to be sister to Monimiaceae, regardless of whether the longest branched groups, Calycanthus, Siparuna, and Cassytha, are included or excluded. Support for this family grouping remained consistently low ( $56 \%$ included all taxa).

Parsimony analysis of the concatenated sequences resulted in a single shortest tree found in all random addition replicates (length $=1969$ steps; consistency index $=0.70$; retention index $=0.74$; fig. 3 ). Parsimony showed Monimiaceae and Lauraceae to be sister groups (59\% bootstrap support). The same topology and similar low bootstrap values were obtained when species of Hernandiaceae with incomplete sequences were excluded.

A Kishino-Hasegawa test (implemented in PAUP), which tests the difference between two log-likelihood scores, shows that the likelihoods of the alternative topologies, (Lauraceae + Monimiaceae) Hernandiaceae, (Lauraceae + Hernandiaceae) Monimiaceae, and (Monimiaceae + Hernandiaceae) Lauraceae, are not significantly different. Shi- modaira and Hasegawa (1999) recently pointed out that the Kishino-Hasegawa test tends to reject alternative topologies too readily, leading to overconfidence in wrong "best" topologies. By the same token, the failure of the test to reject any of the three topologies supports the notion that current data cannot distinguish among them.

To learn more about the sites that support each of the three possible topologies, we examined the character changes supporting them. Twenty-one base pairs change along the $\mathrm{L}+$ $M$ stem in the parsimony tree (fig. 3); all but one of them are homoplasious. The unambiguous character is a transversion ( $\mathrm{T}$ to $\mathrm{A}$ ) in the $p s b \mathrm{~A}-t r n \mathrm{H}$ spacer (reversed only in higher Lauraceae). The other characters supporting $L+M$ are five substitutions in the rpl16 intron, four in the $\operatorname{trn} \mathrm{T}-\operatorname{trn} \mathrm{L}$ spacer, five in the $t r n \mathrm{~L}-t r n \mathrm{~F}$ spacer, and six changes in the $26 \mathrm{~S}$ expansion regions. An $\mathrm{M}+\mathrm{H}$ grouping is supported by three changes in $t r n \mathrm{~L}-t r n \mathrm{~F}$ and by six changes in the $26 \mathrm{~S}$ expansion regions; an $\mathrm{L}+\mathrm{H}$ grouping is supported solely by six changes in the $26 \mathrm{~S}$ expansion regions. All of these potentially syna-

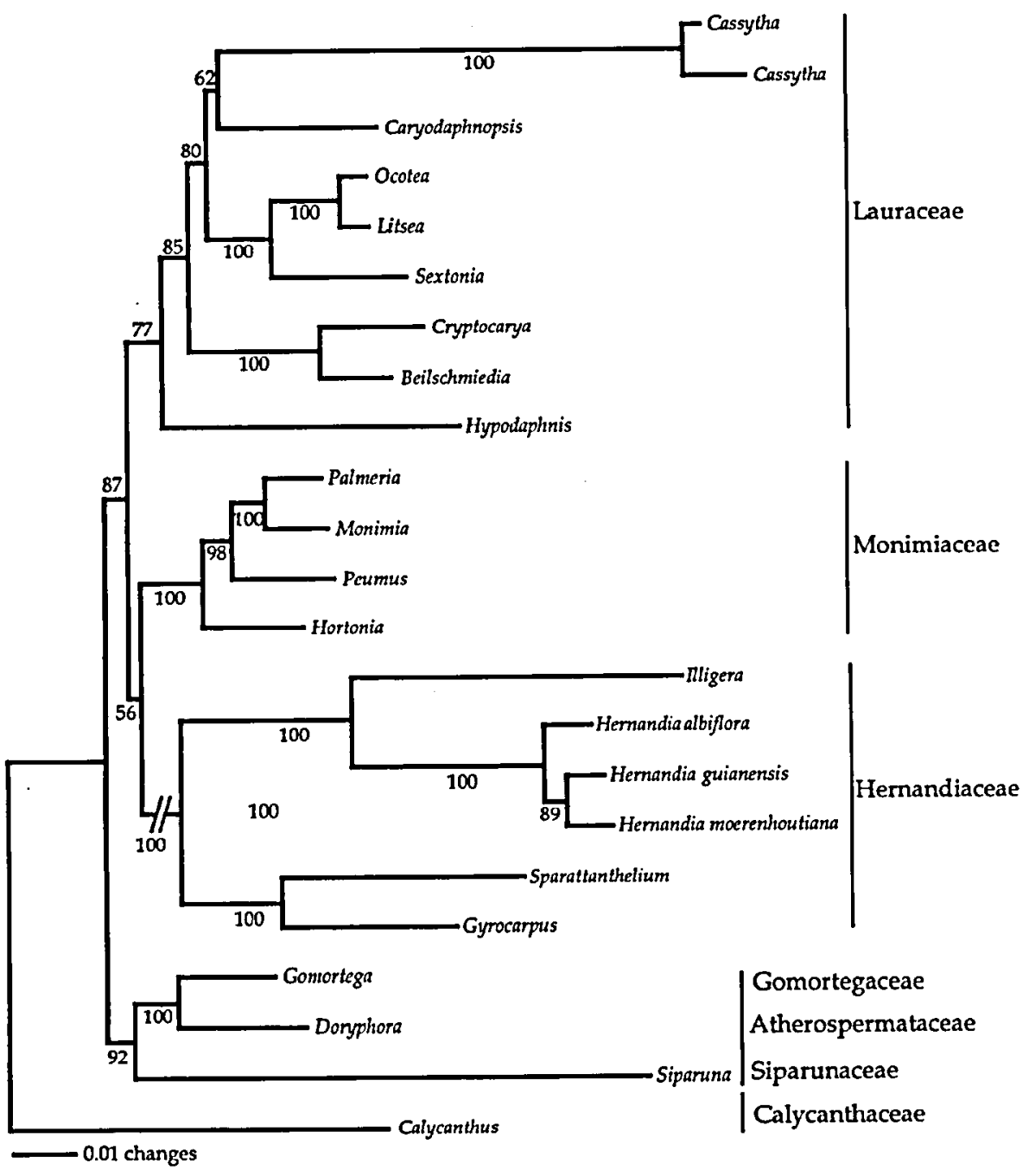

Fig. 2 Minimum evolution tree, using LogDet distances for Hernandiaceae, Lauraceae, and Monimiaceae. Bootstrap values below branches are based on 1000 replicates. The branch leading to Hernandiaceae is shortened by one-half. 


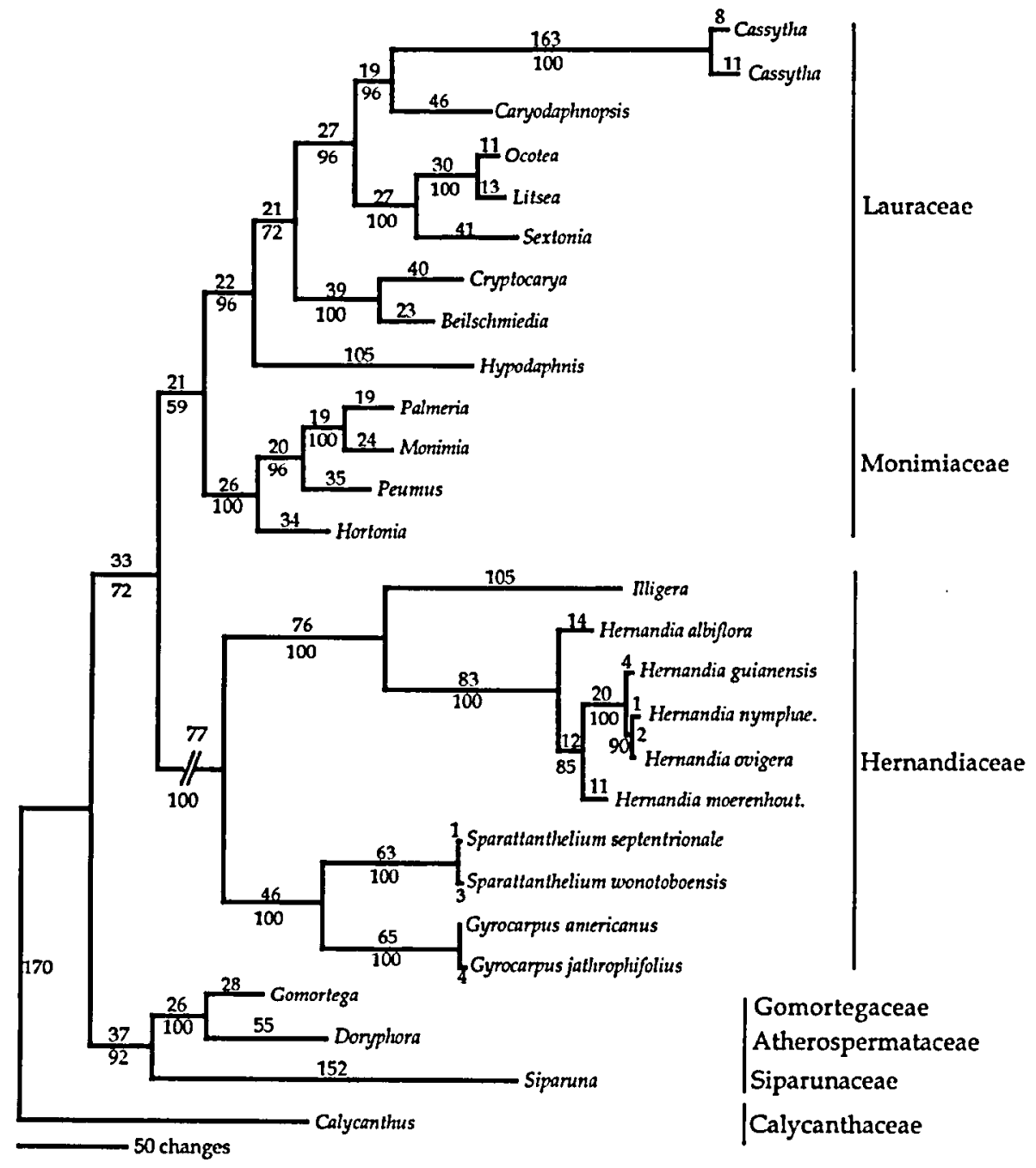

Fig. 3 The single most parsimonious tree for Hernandiaceae, Lauraceae, and Monimiaceae (length $=1969$ steps, consistency index $=$ 0.70 , retention index $=0.74$ ). Figures above branches give the number of substitutions along a branch; figures below branches are bootstrap values based on 1000 replicates. The branch leading to Hernandiaceae is shortened by one-half.

pomorphic changes involve nucleotides that also change elsewhere in the data set.

\section{Discussion}

The results of this study confirm earlier morphological and molecular work showing that Hernandiaceae, Lauraceae, and Monimiaceae are closely related. Even large amounts of sequence data, however, do not robustly resolve relationships among these three families. Thus, neither concatenated sequences from five genes from all three plant genomes (Qiu et al. 1999; albeit, this holds true for a smaller sample of HLM taxa, since Laurales were not the focus of the Qiu et al. study) nor the more variable DNA regions concatenated here contain the right number of conserved substitutions. Poor ingroup taxon sampling is unlikely as a cause of the problem, because each of the three families is sufficiently well understood, from a molecular sampling point of view, to permit correct taxon choice. Lauraceae and Monimiaceae are each represented by several genera that represent the deepest splits in these families (Renner 1998, 1999; Renner and Zanis 1999; Rohwer 2000; Chanderbali et al., in press). Hernandiaceae are represented by several species, representing four of their five genera. Kubitzki recently (1993) segregated a monotypic Madagascan subgenus of Hernandia as a separate genus, but he now sees Hazomalania voyroni as being derived within Hernandia ( $\mathrm{K}$. Kubitzki, personal communication to S. S. Renner, 2000). Sampling problems may still exist, however, as a result of the extinction of basal HLM genera during the 100-million-year-long history of the clade.

Simulation studies have shown that correct phylogenetic reconstruction can be hampered by heterogeneity in molecular evolutionary rates among lineages or sites, but that except in extreme cases, it should be possible to reconstruct the correct tree by appropriate selection of methods, models, and parameters (Felsenstein 1988; Li 1997; Siddall 1998). However, 
among-lineage rate heterogeneity is unlikely to be the cause of the difficult reconstruction of HLM relationships. First, exclusion of fast-evolving taxa had no effect on topology or bootstrap support for family relationships. Second, our trees show long and short branches that are interspersed, regardless of tree reconstruction method, except in the case of Monimiaceae, which form a uniformly short-branched clade. Simulations using matrices with up to ninefold substitution rate differences among taxa indicate that $\mathrm{ML}$ may be robust against unequal rate effects ( $\mathrm{Li}$ 1997, p. 135). Neighbor joining, too, is considered robust against unequal rates, as long as distances are estimated accurately (Felsenstein 1988; Li 1997). Rate differences across sites rather than taxa also are unlikely to be the cause of the difficult reconstruction of HLM relationships. The gamma parameter estimated for the concatenated data, $\alpha=$ 0.94 , indicates that substitution rate is almost homogeneous. Only the $26 \mathrm{~S}$ gene $(\alpha=0.55)$ shows moderately strong among-site rate heterogeneity. In addition, different base composition among lineages is not a problem (table 2).

There is also no statistically supported conflict among trees obtained from the nuclear data (i.e., the large subunit $26 \mathrm{~S}$ rDNA) and trees obtained from the chloroplast data. However, the tree obtained from the $26 \mathrm{~S}$ data is the only one in which the three families are not monophyletic, which indicates that there may be a difference between the nuclear and chloroplast data that might be explored further. We know of no examples of hybridization within or among Lauraceae, Hernandiaceae, or Monimiaceae, but these are predominantly tropical, woody groups, the biology of which is not well known. Perhaps tellingly, Hernandiaceae and Monimiaceae share the presence of extensive polyploid series, such as $n=10,20,30$ or $n=24,48$ in the former and $n=19,39,40-42,50$, and up to 90 in the latter (Morawetz 1986). By contrast, Lauraceae almost uniformly have a chromosome base number of $n=12$ (Rohwer 1993).

Lack of a clear answer to the question regarding relationships among Hernandiaceae, Lauraceae, and Monimiaceae in this and previous studies (Qiu et al. 1999; Renner 1999) thus appears to be the result primarily of insufficient phylogenetic information along the internal branch that separates two of these families from the third. This implies that there exists a striking difference between molecular and morphological evolution in this part of the Laurales. In an angiosperm-wide morphological cladistic analysis, Doyle and Endress (2000) have found $100 \%$ bootstrap support for a sister group relationship between Lauraceae and Hernandiaceae, making this one of the best-supported relationships in their tree. Why would such a strong morphological signal not be paralleled by the molecular signal analyzed here? In other lauralean clades, the amount of molecular change seen in the very same genome regions seems to parallel morphological change closely. For example, Calycanthaceae differ by many autapomorphic morphological changes from the remaining families of Laurales, and they also have a long branch in molecular studies (Qiu et al. 1999; Renner 1999; this study). Cassytha, the hemiparasitic twiner whose precise placement in Lauraceae has been unclear because of numerous autapomorphies (Rohwer 1993, 2000; Chanderbali et al., in press), has accumulated numerous unique molecular changes (figs. 1-3).

Although morphological investigations by themselves will not solve the current impasse, it is important to consider the possible morphological support for alternative topologies. The traditional view is that Lauraceae and Hernandiaceae are closer to each other than either is to Monimiaceae. Morphological arguments for this theory come mainly from the unicarpellate condition fixed in these two families alone among Laurales as well as from their loss of a persistent endosperm. Among other Laurales, an endosperm is also absent in mature seeds of Calycanthaceae, and solitary carpels are also found in Calycanthaceae (Idiospermum) and in higher Monimiaceae (Xymalos, Hennecartia). The remaining Laurales, including all basal Monimiaceae, have numerous carpels per flower. Importantly, Hernandiaceae have epigynous flowers (elsewhere in Laurales, these flowers are only found in Gomortega), as does a monotypic, possibly basal genus of Lauraceae, Hypodapbnis (Rohwer 2000; Chanderbali et al., in press). Other Lauraceae and most Monimiaceae are perigynous. In terms of stamen structure, Lauraceae (with tetrasporangiate anthers) and Hernandiaceae (with disporangiate anthers) share valvate anther opening, whereas Monimiaceae anthers dehisce longitudinally or transversally. In only a few Monimiaceae do anthers have short lateral incisions at the top and bottom of the longitudinal slits, resulting in a saloon door-like opening of the thecae (Baillon 1869, fig. 339; Endress and Hufford 1989, figs. 83-84). As in an earlier morphological cladistic analysis of Laurales (Renner et al. 1997) and as found by Doyle and Endress (2000) in a much broader analysis of morphological and anatomical characters of basal angiosperms, a sister group relationship between Monimiaceae and Hernandiaceae or between Lauraceae and Monimiaceae appears to receive no support from morphology or anatomy.

The fundamental question raised by this and prior studies is how the contrast between a series of potentially shared complex morphological characters and the absence of shared molecular characters (in the sampled data) can best be understood. Perhaps genome regions other than the ones sequenced so far changed coincidentally with morphological characters and are under similar stabilizing selection. Sequencing such regions might enable one to pick up congruent signals from molecules and morphology. Thus, we see two ways to further attack "the HLM problem." One way is to augment DNA data by supplementing the existing atp $\mathrm{B}, r b c \mathrm{~L}$, atp 1 , mat $\mathrm{R}$, and $18 \mathrm{~S}$ rDNA data set of Qiu et al. (1999) for a sample of the key genera newly sampled here and to also sequence the remaining $80 \%$ of the 26S gene for all key taxa. These taxa include Hypodaphnis, Beilschmiedia, Cassytha, Caryodaphnopsis, and Sextonia (Lauraceae) and Illigera, Sparattanthelitum, and Hernandia (Hernandiaceae). Adding these data to the spacers and introns sequenced here would bring the total number of nucleotides up to almost 12,000 bp and may well yield enough phylogenetic signal to resolve the HLM trichotomy. Alternatively-and this is the strategy we favor-one could sequence one or more low-copy nuclear genes, which are providing strong phylogenetic signals in other basal angiosperms, especially monocots (Soltis and Soltis 1998; Mathews et al. 2000 and references cited therein). These genes may be evolving in different ways from the regions sampled so far and thus may represent more informative data. 


\section{Acknowledgments}

We thank J. Rohwer for critical comments on the manuscript and two anonymous reviewers for valuable suggestions. The botanical gardens of Adelaide, Brisbane, Colombo, Edinburgh, Lawai (Kauai, Hawaii), Missouri, Munich, and Sydney and the individual collectors J. Bradford, D. Foreman, B. Hammel, B. Hyland, D. Strasberg, and $H$. van der Werff are thanked for generously providing leaf material. We are grateful to D. Soltis and M. Zanis for six (during the course of our study) unpublished $26 \mathrm{~S}$ sequences. This research was supported by grants from the University of Missouri system and the University of Missouri-St. Louis.

\section{Appendix}

\section{Table A1}

Sources of Plant Material and GenBank Accession Numbers for the Phylogenetic Analysis of Laurales

\begin{tabular}{|c|c|c|c|c|c|c|}
\hline \multirow[b]{2}{*}{ Species } & \multicolumn{4}{|c|}{ Chloroplast regions } & \multirow{2}{*}{$\frac{\text { Nuclear region }}{26 \mathrm{~S}}$} & \multirow[b]{2}{*}{ Source or voucher } \\
\hline & $r p / 16$ & 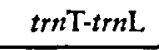 & $\operatorname{trn\mathrm {L}-trn\mathrm {F}}$ & $p s b \mathrm{~A} \cdot t r n \mathrm{H}$ & & \\
\hline \multicolumn{7}{|l|}{ Hernandiaceae: } \\
\hline Gyrocarpus americanus & & & & & & \\
\hline $\begin{array}{c}\text { Jacq. ........................................ } \\
\text { Gyrocarpus jatrophifolius }\end{array}$ & AF127261 & AF129025 & AF012398 & AF129054 & AF262001 & Chase 317 (NCU) \\
\hline 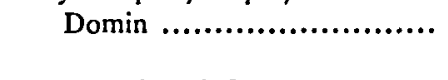 & $\cdots$ & AF233597 & AF232026 & $\cdots$ & ... & $\begin{array}{l}\text { Zamora and Hammel } \\
1883 \text { (INB) }\end{array}$ \\
\hline $\begin{array}{l}\text { Hernandia albiflora } \\
\text { (C. T. White) Kubitzki ......... } \\
\text { Hernandia guianensis }\end{array}$ & $\cdots$ & AF233598 & AF232027 & $\cdots$ & $\cdots$ & Jago 4689 (NSW) \\
\hline $\begin{array}{c}\text { Aublet } \\
\text { Hernandia moerenhoutiana }\end{array}$ & AF127263 & AF233599 & AF232028 & AF261993 & $\ldots *$ & Munich BG \\
\hline Guillem. .................. & AF130310 & AF129026 & AF052198 & AF129055 & $\ldots^{*}$ & Brisbane BG \\
\hline 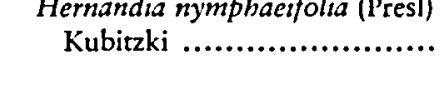 & ... & AF233600 & AF232029 & $\ldots$ & AF264139*. & $\begin{array}{l}\text { Natl. BG Hawaii 960860; } \\
\text { Zurich BG }\end{array}$ \\
\hline $\begin{array}{l}\text { Hernandia ovigera L. .............. } \\
\text { Illigera luzonensis (Presl) }\end{array}$ & $\cdots$ & AF233601 & AF232030 & AF261994 & ... & Munich BG \\
\hline $\begin{array}{c}\text { Merr. } \\
\text { Sparattanthelium septentrionale }\end{array}$ & AF127264 & AF129030 & AF052199 & AF129057 & AF262002 & Munich BG \\
\hline $\begin{array}{c}\text { Sandw. } \\
\text { Sparattanthelium wonotoboensis }\end{array}$ & $\cdots$ & AF233602 & AF232031 & $\ldots$ & AF262003* & Aguilar 5589 (INB) \\
\hline $\begin{array}{c}\text { Kosterm. ................................. } \\
\text { Lauraceae: }\end{array}$ & AF127262 & AF129043 & AF053342 & AF129070 & $\ldots *$ & Munich BG 97/134 \\
\hline Beilschmiedia brenesii & & & & & & \\
\hline $\begin{array}{l}\text { C. K. Allen ................................... } \\
\text { Beilschmiedia tilaranensis }\end{array}$ & $\cdots$ & $\cdots$ & ... & $\cdots$ & AF262004* & Yasuda 1314 (MO) \\
\hline $\begin{array}{l}\text { Sa. Nishida ............................ } \\
\text { Caryodaphnopsis bilocellata van }\end{array}$ & AF127265 & AF129015 & AF129014 & AF129045 & $\ldots *$ & Yasuda 1313 (MO) \\
\hline der $\mathrm{W}$ & AF232743 & AF233603 & AF232032 & AF261995 & AF262005 & van der Werff 141 \\
\hline Cassytha fliformis L. ............. & AF232744 & AF233605 & AF232034 & AF261996 & AF262006 & Chanderbali 205 (MO) \\
\hline $\begin{array}{l}\text { Cassytha pubescens } \mathrm{R} . \mathrm{Br} . \ldots . . . \\
\text { Cryptocarya thouvenotii }\end{array}$ & ... & AF233604 & AF232033 & $\ldots$ & AF262007 & Foreman 1913 (MEL) \\
\hline $\begin{array}{l}\text { (Danguy) Kosterm. ............. } \\
\text { Hypodaphnis zenkeri (Engl.) }\end{array}$ & AF232745 & AF233606 & AF232035 & AF261997 & AF262008 & van der Werff $12723(\mathrm{MO})$ \\
\hline 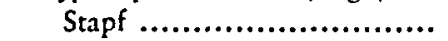 & AF232746 & AF233607 & AF232036 & AF261998 & AF262009 & McPherson $16184(\mathrm{MO})$ \\
\hline Litsea coreana Leveille ........... & $\ldots$ & $\ldots$ & $\ldots$ & $\ldots$ & AF262010* & Yasuda $1356(\mathrm{MO})$ \\
\hline $\begin{array}{l}\text { Litsea glaucescens Kunth .......... } \\
\text { Ocotea grayi }\end{array}$ & AF127266 & AF129036 & AF129035 & AF129063 & $\ldots *$ & Lorea 5496 (MO) \\
\hline $\begin{array}{l}\text { van der Werff ....................... } \\
\text { Ocotea quixos (Lam.) }\end{array}$ & AF $232747^{*}$ & $\ldots$ & $\cdots$ & & $\cdots$ & van der Werff 12732 (MO) \\
\hline $\begin{array}{l}\text { Kosterm. ..................................... } \\
\text { Sextonia pubescens }\end{array}$ & ...* & AF233608 & AF232037 & AF261999 & AF262011 & Missouri BG 990585 \\
\hline van der Werff .................... & AF232748 & AF233609 & AF232038 & AF262000 & AF262012 & Vasquez $25229(\mathrm{MO})$ \\
\hline
\end{tabular}


Table A1

(Continued)

\begin{tabular}{|c|c|c|c|c|c|c|}
\hline \multirow[b]{2}{*}{ Species } & \multicolumn{4}{|c|}{ Chloroplast regions } & \multirow{2}{*}{$\frac{\text { Nuclear region }}{26 \mathrm{~S}}$} & \multirow[b]{2}{*}{ Source or voucher } \\
\hline & $r p l 16$ & $\operatorname{trn} \mathrm{T}-t r n \mathrm{~L}$ & $\operatorname{trnL} \mathrm{L} t r n \mathrm{~F}$ & $p s b \mathrm{~A}-t m \mathrm{H}$ & & \\
\hline \multicolumn{7}{|l|}{ Monimiaceae: } \\
\hline 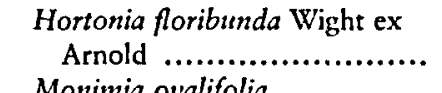 & AF129027 & AF129028 & AF040683 & AF129071 & AF264143a & Colombo BG \\
\hline Monimia ovalifolia & & & & & & \\
\hline $\begin{array}{l}\text { Thouars ................................... } \\
\text { Palmeria scandens }\end{array}$ & AF127269 & AF129038 & AF054896 & AF129065 & AF264144" & Strasberg s.n. (REU) \\
\hline F. Muell. ......................... & AF 127270 & AF129040 & AF052200 & AF129067 & AF264142 & Bradford $878(\mathrm{MO})$ \\
\hline Peumus boldus Molina .......... & AF 127454 & AF129041 & AF012403 & AF129068 & AF264141" & Edinburgh BG 19870707 \\
\hline \multicolumn{7}{|l|}{$\begin{array}{l}\text { Outgroups: } \\
\text { Atherospermataceae: }\end{array}$} \\
\hline $\begin{array}{l}\text { Endl. .................................... } \\
\text { Calycanthaceae: }\end{array}$ & AF127252 & AF129023 & AF040672 & AF129050 & AF262013 & Sydney BG 18026 \\
\hline $\begin{array}{l}\text { Calycanthus occidentalis } \\
\text { Hook. \& Arn. ............... } \\
\text { Gomortegaceae: }\end{array}$ & AF127250 & AF129017 & AF012396 & AF129046 & AF264145" & Missouri BG 897432 \\
\hline Gomortega nitida & & & & & & \\
\hline $\begin{array}{l}\text { R. \& P. ................................ } \\
\text { Siparunaceae: }\end{array}$ & AF127260 & AF264020 & AF012404 & AF129053 & AF262014 & Rodriguez 3070 (CONC) \\
\hline Siparuna aspera (R. \& P.) & & & & & & \\
\hline 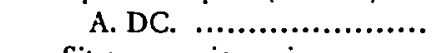 & $\ldots *$ & AF129042 & AF040695 & AF129069 & AF262015 & Madriñán et al. 1502 (COL) \\
\hline $\begin{array}{l}\text { Siparuna guianensis } \\
\text { Aublet ....................... }\end{array}$ & & & & & & \\
\hline 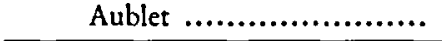 & AF127455* & $\ldots$ & $\ldots$ & $\ldots$ & $\ldots$ & Chanderbali 247 (MO) \\
\hline
\end{tabular}

Note. Herbarium vouchers are deposited in the following herbaria: the Missouri Botanical Garden (MO), Colombian National Herbarium (COL), University of North Carolina (NCU), Réunion (REU), Concepción (CONC), New South Wales (NSW), Melbourne (MEL), Queensland (QRS), and the National Biological Institute in Costa Rica (INB). Botanical Gardens (BG) are cited for cultivated plants. Sequences marked with an asterisk were used to complement the set of sequences in the line directly above or below them (also with an asterisk).

'D. Soltis and M. Zanis, unpublished manuscript.

\section{Literature Cited}

APG 1998 An ordinal classification for the families of flowering plants. Ann Mo Bot Gard 85:531-553.

Asmussen CB 1999 Toward a chloroplast DNA phylogeny of the tribe Geonomeae (Palmae). Pages 121-129 in A Henderson, F Borchsenius, eds. Evolution, variation, and classification of palms. Mem N Y Bot Gard 83:121-129.

Baillon HE 1869 Histoire des plantes. Vol 1. L. Hachette \& Cie, Paris. Bremer B, RK Jansen, B Oxelman, M Backlund, H Lantz, K-J Kim 1999 More characters or more taxa for a robust phylogeny-a case study from the coffee family (Rubiaceae). Syst Biol 48:413-435.

Chanderbali AS, $H$ van der Werff, SS Renner In press The relationships and historical biogeography of Lauraceae: evidence from the chloroplast and nuclear genomes. Ann Mo Bot Gard.

Chase MW, et al. 1993 Phylogenetics of seed plants: an analysis of nuclcotide sequences from the plastid gene $r b c L$. Ann Mo Bot Gard 80:528-580.

Cummings MP, SP Otto, J Wakeley 1995 Sampling properties of DNA sequence data in phylogenetic analyses. Mol Biol Evol 12: 814-822.

Doyle JA, MJ Donoghue, EA Zimmer 1994 Integration of morphological and ribosomal RNA data on the origin of angiosperms. Ann Mo Bot Gard 81:419-450.

Doyle JA, E Endress 2000 Morphological phylogenetic analysis of basal angiosperms: comparison and combination with molecular data. Int J Plant Sci 161(suppl):S121-S153.
Eklund H 1999 Big survivors with small flowers. PhD diss. University of Stockholm, Stockholm, Sweden.

Eklund H, J Kvacek 1998 Lauraceous inflorescences and flowers from the Cenomanian of Bohemia (Czech Republic, Central Europe). Int J Plant Sci 159:668-686.

Endress PK, LD Hufford 1989 The diversity of stamen structures and dehiscence patterns among Magnoliidae. Bot J Linn Soc 100:45-85.

Felsenstein J 1985 Confidence limits on phylogenies: an approach using the bootstrap. Evolution 39:783-791.

1988 Phylogenies from molecular sequences: inference and reliability. Annu Rev Genet 22:521-565.

Graybeal A 1998 Is it better to add taxa or characters to a difficult phylogenetic problem? Syst Biol 74:9-17.

Gunderson A 1950 Families of dicotyledons. Chronica Botanica, Waltham, Mass.

Hallier H 1905 Ein zweiter Entwurf des natürlichen (phylogenetischen) systems der Blütenpflanzen. Ber Dtsch Bot Ges 23:85-91.

Hasegawa M, H Kishino, K Yano 1985 Dating of the human-ape splitting by a molecular clock of mitochondrial DNA. J Mol Evol 22:160-174.

Hillis DM 1996 Inferring complex phylogenies. Nature 383:130-131.

Kim J 1998 Large-scale phylogenies and measuring the performance of phylogenetic estimators. Syst Biol 47:43-60.

Kubitzki K 1969 Monographie der Hernandiaceen. Bot Jahrb Syst 89: 78-148.

- 1993 Hernandiaceae. Pages 334-338 in K Kubitzki, JG Roh- 
wer, $V$ Bittrich, eds. The families and genera of vascular plants. Vol 2. Springer, Berlin.

Kuhner MK, J Felsenstein 1994 A simulation comparison of phylogeny algorithms under equal and unequal evolutionary rates. Mol Biol Evol 11:459-468.

Kuzoff RK, JA Sweere, DE Soltis, PS Soltis, EA Zimmer 1998 The phylogenetic potential of entire $26 \mathrm{~S}$ rDNA sequences in plants. Mol Biol Evol 15:251-263.

Lake JA 1994 Reconstructing evolutionary trees from DNA and protein sequences: paralinear distances. Proc Natl Acad Sci USA 91: 1455-1459.

Lecointre G, H Philippe, HL Van Le, H Le Guyader 1993 Species sampling has a major impact on phylogenetic inference. Mol Phylogenet Evol 2:205-224.

Li W-H 1997 Molecular evolution. Sinauer, Sunderland, Mass.

Lockhart PJ, MA Steel, MD Hendy, D Penny 1994 Recovering evolutionary trees under a more realistic model of sequence evolution. Mol Biol Evol 11:605-612.

Lyons-Weiler J, GA Hoelzer, RJ Tausch 1998 Optimal outgroup analysis. Biol J Linn Soc 64:493-511.

Maddison WT, DR Maddison 1992 MacClade: analysis of phylogeny and character evolution (version 3). Sinauer, Sunderland, Mass.

Mathews S, RC Tsai, EA Kellogg 2000 Phylogenetic structure in the grass family (Poaceae): evidence from the nuclear gene phytochrome B. Am J Bot 87:96-107.

Meissner CF 1864 Lauraceae. Pages 1-260 in A de Candolle, ed. Prodromus systematis naturalis regni vegetabilis. Vol 15.2. Fortin, Masson, Paris.

Morawetz W 1986 Remarks on karyological differentiation patterns in tropical woody plants. Plant Syst Evol 152:49-100.

Poe S, DL Swofford 1999 Taxon sampling revisited. Nature 398: 299-300.

Qiu Y-L, J Lee, F Bernasconi-Quadroni, DE Soltis, PS Soltis, M Zanis, EA Zimmer, Z Chen, V Savolainen, MW Chase 1999 The earliest angiosperms: evidence from mitochondrial, plastid and nuclear genomes. Nature 402:404-407.

Rannala B, JP Huelsenbeck, Z Yang, R Nielsen 1998 Taxon sampling and the accuracy of large phylogenies. Syst Biol 47:702-710.

Renner SS 1998 Phylogenetic affinities of Monimiaceae based on cpDNA gene and spacer sequences. Perspect Plant Ecol Evol Syst 1:61-77.

1999 Circumscription and phylogeny of the Laurales: evidence from molecular and morphological data. Am J Bot 86: 1301-1315.

Renner SS, D Murray, D Foreman 2000 Timing transantarctic disjunctions in the Atherospermataceae (Laurales): evidence from coding and noncoding chloroplast sequences. Syst Biol 49:383-396.

Renner SS, AE Schwarzbach, L. Lohmann 1997 Phylogenetic position and floral function of Siparuna (Siparunaceae: Laurales). Int J Plant Sci 158(suppl):S89-S98.

Renner SS, M Zanis 1999 A phylogeny of the Monimiaceae based on cpDNA and nuclear data. XVI International Botanical Congress, Abstract 20.1.3, p. 250.
Rohwer J 1993 Lauraceae. Pages 366-391 in K Kubitzki, JG Rohwer, $\mathrm{V}$ Bittrich, eds. The families and genera of vascular plants. Vol 2. Springer, Berlin.

2000 Toward a phylogenetic classification of the Lauraceae: evidence from mat $K$ sequences. Syst Bot 25:60-71.

Sang T, DJ Crawford, TF Stuessy 1997 Chloroplast DNA phylogeny, reticulate evolution, and biogeography of Paconia (Paeoniaceae). Am J Bot 84:1120-1136.

Shimodaira H, M Hasegawa 1999 Multiple comparisons of log-likelihoods with applications to phylogenetic inference. Mol Biol Evol 16:1114-1116.

Shutts CF 1960 Wood anatomy of Hernandiaceae and Gyrocarpaceae. Trop Woods 113:85-123.

Siddall ME 1998 Success of parsimony in the four-taxon case: longbranch repulsion by likelihood in the Farris zone. Cladistics 14: 209-220.

Soltis DE, PS Soltis 1998 Choosing an approach and an appropriate gene for phylogenetic analysis. Pages $1-42$ in DE Soltis, PS Soltis, JJ Doyle, eds. Molecular systematics of plants. Vol 2. Kluwer Academic, Boston.

Soltis DE, PS Soltis, ME Mort, MW Chase, V Savolainen, SB Hoot, CM Morron 1998 Inferring complex phylogenies using parsimony: an empirical approach using three large data sets for angiosperms. Syst Biol 47:32-42.

Strimmer K, A von Haeseler 1996 Quartet puzzling: a quartet maximum-likelihood method for reconstructing tree topologies. Mol Biol Evol 13:964-969.

Sullivan J, DL Swofford, GJP Naylor 1999 The effect of taxon sampling on estimating rate heterogeneity parameters of maximum-likelihood models. Mol Biol Evol 16:1347-1356.

Swofford DL 1998 PAUP*: phylogenetic analysis using parsimony ("and other methods), version 4. Sinauer, Sunderland, Mass.

Swofford DL, GJ Olsen, PJ Waddel, DM Hillis 1996 Phylogenetic inference. Pages 407-514 in DM Hillis, C Moritz, BK Mable, eds. Molecular systematics. 2d ed. Sinauer, Sunderland, Mass.

Taberlet P, L Gielly, G Pautou, J Bouvet 1991 Universal primers for amplification of three non-coding regions of chloroplast DNA. Plant Mol Biol 17:1105-1109.

Takezaki N, T Gojobori 1999 Correct and incorrect vertebrate phylogenies obtained by the entire mitochondrial DNA sequences. Mol Biol Evol 16:590-601.

Takhtajan A 1973 Evolution und Ausbreitung der Blütenpflanzen. Gustav Fischer, Jena.

1997 Diversity and classification of flowering plants. Columbia University Press, New York.

Yang Z 1994 Maximum likelihood phylogenetic estimation from DNA sequences with varjable rates over sites: approximate methods. J Mol Evol 39:306-314.

1996 Among-site rate variation and its impact on phylogenetic analyses. Trends Ecol Evol 11:367-372.

Yang Z, S Kumar 1996 Approximate methods for estimating the pattern of nucleotide substitution and the variation of substitution rates among sites. Mol Biol Evol 13:650-659. 